\title{
Milk Iodine Content in Slovakia
}

\author{
I. PAULÍKOVÁ, H. SEIDEL, O. NAGY, G. KOVÁC̆ \\ University of Veterinary Medicine, Košice \\ Received December 20, 2007 \\ Accepted July 7, 2008
}

\begin{abstract}
Paulíková I., H. Seidel, O. Nagy, G. Kováč: Milk Iodine Content in Slovakia. Acta Vet. Brno 2008, 77: 533-538.

The aim of this work was to map actual iodine status and its seasonal differences in raw milk of dairy cows, sheep, and goats in various regions of Slovakia. Iodine concentrations were determined in 457 samples of raw milk from dairy cows, 78 samples of sheep, and 16 samples of goat milk collected in various regions of Slovakia from 2002 to 2007. Among all the 457 samples of bovine milk, iodine content below $50 \mu \mathrm{g} \cdot \mathrm{l}^{-1}$ was recorded in 114 samples $(24.94 \%)$; 294 samples $(64.33 \%)$ ranged between 50 and $200 \mu \mathrm{g} \cdot \mathrm{l}^{-1} ; 19$ samples $(4.16 \%)$ from 200 to 500 $\mu \mathrm{g} \cdot \mathrm{l}^{-1}$; 17 samples $(3.72 \%)$ between 500 and $1000 \mu \mathrm{g} \cdot \mathrm{l}^{-1}$, and 13 samples $(2.85 \%)$ showed iodine concentrations over $1000 \mu \mathrm{g} \cdot \mathrm{l}^{-1}$. Regional concentrations showed the highest values in the Western, then Middle and Eastern Slovakia, and the lowest values in Northern Slovakia $(p<0.05$, $p<0.01)$. In sheep and goat milk samples, we found iodine concentrations below $80 \mu \mathrm{g} \cdot \mathrm{l}^{-1}$ in 49 sheep $(62.8 \%)$ and in 6 goats below $60 \mu \mathrm{g} \cdot 1^{-1}(37.5 \%)$, which are indicative of iodine deficiency. When comparing seasonal differences, sheep and goat milk had higher iodine content during the winter feeding period, however, in dairy cows we recorded the opposite ratio. Except for goat milk $(p<0.01)$ the seasonal differences were not significant.
\end{abstract}

Iodine, raw milk, cows, sheep, goats, season

Iodine as an essential element is incorporated into the chemical structure of thyroidal hormones. Iodine deficiency leads to serious health disorders both in humans and animals of all ages. However, iodopaenia is frequently only subclinical without clinical signs, thus affecting farm economy. Milk is one of the most important sources of iodine in human nutrition (Herzig and Suchý 1996; Borkovcová and Řehuřrková 2001), with milk and its products representing over 50\% of the total iodine intake (Park et al. 1981; Dellavalle and Barbano 1984). For example, Krajčovičová-Kudláčková et al. (2001) found in their experiment that the intake of purely plant foods induced signs of iodine deficiency in humans (urine iodine content below $100 \mu \mathrm{g} \cdot \mathrm{l}^{-1}$ ).

As the milk iodine concentration changes readily in response to its dietary intake, it is a good indicator of momentary or recent iodine intake in the case of a relatively steady ration without goitrogens. Milk iodine concentrations depend on various factors, first of all on the dietary intake (Swanson et al. 1990; Kroupová et al. 2001), but also on the season (Binnerts 1979; Groppel and Anke 1991; Dahl et al. 2003; Trávníček et al. 2006), food processing (Herzig and Suchý 1996; Bobek 1998), environmental temperature (Lengemann 1979), and food harvesting time (Trávníček et al. 2004).

Iodine intake necessary to maintain its plasma levels over the critical threshold $10 \mu \mathrm{g}$ per $100 \mathrm{ml}$ (in which goitre development is probable), is $120 \mu \mathrm{g}$ per day. As sufficient daily iodine intake in adults and adolescents, $150 \mu \mathrm{g}$ are recommended (Wayne et al. 1964). Higher iodine intake is not desirable because it decreases its bioavailability and leads to goitre (Anke et al. 1998). In human medicine, iodine intake in the long term should not exceed $2000 \mu \mathrm{g}$ in adults and $1000 \mu \mathrm{g}$ in children (Wolff 1969). A long-term intake of iodides in amounts exceeding ten times the daily requirements for biosynthesis of thyroidal hormones may result in goitre or thyreotoxicosis (Wolff 1969; Braverman et al. 1971).

Address for correspondence:

MVDr. Iveta Paulíková

University of Veterinary Medicine

Komenského 73, 04181 Košice

Slovak Republic
Phone: +421915986694

Fax.: +421556323173

E-mail: iveta.paulikova@post.sk

http://www.vfu.cz/acta-vet/actavet.htm 
The primary aim of this work was to determine the iodine content in raw milk of dairy cows, sheep, and goats regardless of breed, production, and reproduction cycle. The second goal was to compare milk iodine levels in various regions of Slovakia, as well milk iodine concentrations during winter and summer feeding periods.

\section{Materials and Methods}

Milk iodine concentrations were determined in 457 samples of raw milk from dairy cows, 79 samples of sheep, and 17 samples of goat milk collected in various regions of Slovakia from 2002 to 2007. The samples were taken manually after washing of quarters and halves, respectively, without the use of iodine disinfectant. Animals from 32 farms (dairy cows - 23, sheep - 7, goats - 2) were divided into four groups according to the regions - Western (162 cows), Middle ( 24 cows, 6 goats) Eastern (241 cows, 60 ewes, 10 goats) and Northern (30 cows, 18 ewes) Slovakia. We compared also milk iodine concentrations recorded during the summer (1 May - 31 October; 169 cows, 6 ewes, 6 goats) and winter (1 November - 30 April; 288 cows, 72 ewes, 10 goats) feeding periods. The milk iodine concentrations were determined by photometric method for the analysis of trace iodine based on catalytic reaction $\mathrm{NO}_{2}-\mathrm{SCN}^{-}$(Tušl 1983). As reference values for the iodine content in milk of cows, sheep, and goats we used data published by various authors (Groppel 1993; Anke et al. 1998; Mee and Rogers 1996). The results were summarised, expressed in percentage, means (x), standard deviations (SD), median, minimum, and maximum values; in sum and on corresponding farms. Statistical evaluation of differences was done by one-way ANOVA analysis with subsequent non-paired Student's $t$-test (MS Office Excel 2007).

\section{Results and Discussion}

Milk iodine concentrations in dairy cows found in our survey are presented in Tables $1-5$.

Table 1. Milk iodine concentrations in dairy cows $\left(\mu \mathrm{g} \cdot \mathrm{l}^{-1}\right)$ from various West-Slovakia farms $(\mathrm{x} \pm \mathrm{SD})$

\begin{tabular}{|l|c|c|c|c|c|c|c|c|}
\hline Farm & 1 & 2 & 3 & 4 & 5 & 6 & 7 & 8 \\
\hline $\mathrm{x}$ & 44.1 & 56.3 & 119.9 & 54.6 & 60.3 & 109.4 & 221.6 & 1110.4 \\
\hline SD & 32.5 & 7.8 & 86.3 & 2.5 & 5.0 & 56.2 & 126.3 & 393.2 \\
\hline median & 29.4 & 55.6 & 82.5 & 54.3 & 60.1 & 102.9 & 193.3 & 953.5 \\
\hline min. & 9.2 & 40.6 & 51.6 & 52.0 & 51.9 & 56.7 & 70.2 & 650.0 \\
\hline max. & 92.7 & 84.9 & 337.3 & 59.2 & 68.6 & 273.3 & 497.8 & 1790.6 \\
\hline $\mathrm{n}$ & 27 & 54 & 14 & 11 & 12 & 14 & 18 & 12 \\
\hline
\end{tabular}

min. - minimum individual value

max. - maximum individual value

$\mathrm{n}$ - number of samples

Table 2. Milk iodine concentrations in dairy cows $\left(\mu \mathrm{g} \cdot \mathrm{l}^{-1}\right)$ from various Middle-Slovakia farms $(\mathrm{x} \pm \mathrm{SD})$

\begin{tabular}{|l|c|c|}
\hline Farm & 9 & 10 \\
\hline $\mathrm{x}$ & 259.2 & 48.1 \\
\hline $\mathrm{SD}$ & 401.7 & 1.9 \\
\hline median & 98.1 & 48.6 \\
\hline min. & 47.9 & 43.7 \\
\hline $\max$. & 1182.1 & 50.4 \\
\hline $\mathrm{n}$ & 12 & 12 \\
\hline
\end{tabular}

The iodine content in the milk of dairy cows, as published by various authors, varies within a wide range of 10 to $2000 \mu \mathrm{g} \cdot \mathrm{l}^{-1}$ or more, the most frequent concentration being found within 100-300 $\mu \mathrm{g} \cdot \mathrm{l}^{-1}$ (Hemken 1979; Park et al. 1981; Šucman et al. 1984; Herzig et al. 1999; Trávníček et al. 2006). Park et al. (1981) analysed ca 2500 US dairy farms and found $62 \%$ of farms with a milk iodine content below $200 \mu \mathrm{g} \cdot \mathrm{l}^{-1}, 28 \%$ between 200 and $500 \mu \mathrm{g} \cdot 1^{-1}$, and $7 \%$ from 500 to $1000 \mu \mathrm{g} \cdot \mathrm{l}^{-1}$. Almost $3 \%$ of farms had a milk iodine content over $1000 \mu \mathrm{g} \cdot \mathrm{l}^{-1}$.

Trávníček et al. (2006) presented iodine concentrations in raw bovine milk in the Czech Republic in 2005. In 169 tank samples from 14 areas of South-western Bohemia they found the average concentration of $442.5 \pm 185.6 \mu \mathrm{g} \cdot \mathrm{l}^{-1}(68.6-1000.6)$, when in five regions they recorded a milk iodine content higher than $500 \mu \mathrm{g} \cdot \mathrm{l}^{-1}$. Milk iodine concentrations are also influenced by goitrogens present in the diet. Třináctý et al. (2001) determined $594.8 \pm$ $178.1 \mu \mathrm{g} \cdot \mathrm{l}^{-1}$ in the milk of dairy cows. With the same supply of iodine and simultaneous feeding rapeseed meal (270 $\mathrm{g} \cdot \mathrm{kg}^{-1}$ food) the iodine content in milk decreased to 
Table 3. Milk iodine concentrations in dairy cows $\left(\mu \mathrm{g} \cdot 1^{-1}\right)$ from various NorthernSlovakia farms $(\mathrm{x} \pm \mathrm{SD})$

\begin{tabular}{|l|c|l|}
\hline Farm & 11 & 12 \\
\hline $\mathrm{x}$ & 45.97 & 54.52 \\
\hline $\mathrm{SD}$ & 1.64 & 10.12 \\
\hline median & 45.4 & 50.0 \\
\hline min. & 44.32 & 44.69 \\
\hline max. & 50.55 & 82.91 \\
\hline $\mathrm{n}$ & 12 & 18 \\
\hline
\end{tabular}

$209.4 \pm 145.3 \mu \mathrm{g} \cdot \mathrm{l}^{-1}$. Similarly, Hermansen et al. (1995) reported a decrease in the milk iodine content in dairy cows fed over $4.4 \mathrm{~kg}$ rapeseed per day.

Concerning dairy cow saturation with iodine, Mee and Rogers (1996) suggested the following milk iodine concentrations: very low - below $25 \mu \mathrm{g} \cdot \mathrm{l}^{-1}$; low - 25-38 $\mu \mathrm{g} \cdot \mathrm{l}^{-1}$; marginal - 39-50 $\mu \mathrm{g} \cdot \mathrm{l}^{-1}$; normal 51-300 $\mu \mathrm{g} \cdot \mathrm{l}^{-1}$; and high - over $300 \mu \mathrm{g} \cdot \mathrm{l}^{-1}$. According to Anke et al. (1998) milk iodine concentration of $50 \mu \mathrm{g} \cdot \mathrm{l}^{-1}$ is considered to be normal. On the other hand, dairy industry accepts a maximum milk iodine concentration of $500 \mu \mathrm{g} \cdot \mathrm{l}^{-1}$ (Hemling 2001). In this connection, the Food Code of the Slovak Republic does not state the milk iodine content (www.svssr.sk/sk/legislativa/ kodex/2_07_05.pdf).

Table 4. Milk iodine concentrations in dairy cows $\left(\mu \mathrm{g} \cdot \mathrm{l}^{-1}\right)$ from various Eastern-Slovakia farms $(\mathrm{x} \pm \mathrm{SD})$

\begin{tabular}{|l|c|c|c|c|c|c|c|c|c|c|c|}
\hline Farm & 13 & 14 & 15 & 16 & 17 & 18 & 19 & 20 & 21 & 22 & 23 \\
\hline $\mathrm{x}$ & 56.3 & 87.1 & 839.3 & 52.9 & 57.8 & 55.4 & 67.4 & 345.2 & 64.1 & 62.5 & 46.5 \\
\hline SD & 2.5 & 5.9 & 307.0 & 4.6 & 18.5 & 1.9 & 15.7 & 426.7 & 17.3 & 15.6 & 90.2 \\
\hline median & 56.5 & 87.4 & 846.9 & 52.4 & 50.5 & 55.5 & 65.7 & 155.2 & 58.0 & 55.8 & 9.1 \\
\hline min. & 53.3 & 76.1 & 206.9 & 42.9 & 44.6 & 52.8 & 44.0 & 61.9 & 37.0 & 41.7 & 8.1 \\
\hline $\max$. & 60.6 & 95.1 & 1355.0 & 63.9 & 135.8 & 169.2 & 97.2 & 3065.0 & 103.2 & 91.1 & 230.6 \\
\hline $\mathrm{n}$ & 12 & 12 & 17 & 18 & 87 & 12 & 24 & 12 & 16 & 25 & 6 \\
\hline
\end{tabular}

Table 5. Milk iodine concentrations in dairy cows $\left(\mu \mathrm{g} \cdot \mathrm{l}^{-1}\right)$ from various regions of Slovakia $(\mathrm{x} \pm \mathrm{SD})$

\begin{tabular}{|l|c|c|c|c|c|}
\hline Region & West & Middle & East & North & Total \\
\hline $\mathrm{X}$ & $161.0^{\mathrm{a} . \mathrm{c}}$ & $153.6^{\mathrm{b}}$ & $75.9^{\mathrm{b} . \mathrm{c}}$ & $51.1^{\mathrm{a}}$ & 136.9 \\
\hline SD & 298.0 & 298.0 & 116.4 & 8.9 & 258.2 \\
\hline median & 60.7 & 50.2 & 54.7 & 47.4 & 56.8 \\
\hline min. & 9.2 & 43.7 & 8.1 & 44.3 & 8.1 \\
\hline max. & 1790.6 & 1182.1 & 1501.9 & 82.9 & 1790.6 \\
\hline $\mathrm{n}$ & 162 & 24 & 241 & 30 & 457 \\
\hline
\end{tabular}

Numbers with the same superscipts differ at ${ }^{\mathrm{a}, \mathrm{b}} p<0.05$ and ${ }^{\mathrm{c}} p<0.01$, respectively

In Slovakia, milk iodine concentrations determined in 1970s ranged between 21 and $103 \mu \mathrm{g} \cdot \mathrm{l}^{-1}$ (Görner et al. 1979). The average milk iodine concentration in the nonendemic area was $89.24 \mu \mathrm{g} \cdot \mathrm{l}^{-}$ ${ }^{1}$, in the low-land endemic area $52.57 \mu \mathrm{g} \cdot \mathrm{l}^{-1}$, and in the mountain endemic area 31.02 $\mu \mathrm{g} \cdot 1^{-1}$.

In our observation, in all the 457 examined samples of bovine milk, an iodine content below $50 \mu \mathrm{g} \cdot \mathrm{l}^{-1}$ was recorded

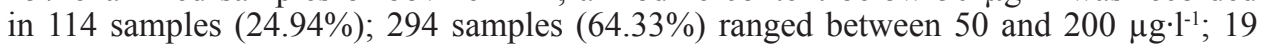
samples $(4.16 \%)$ from 200 to $500 \mu \mathrm{g} \cdot 1^{-1} ; 17$ samples $(3.72 \%)$ between 500 and $1000 \mu \mathrm{g} \cdot 1^{-1}$, and 13 samples $(2.85 \%)$ showed a milk iodine content over $1000 \mu \mathrm{g} \cdot \mathrm{l}^{-1}$. Concentrations in the Slovak regions showed the highest values in the Western, then Middle, Eastern, and the lowest values in Northern Slovakia $(p<0.05, p<0.01$; Table 5). The aforementioned iodine concentrations are substantially higher than those described by Görner et al. (1979). Similar increase in milk iodine concentrations (compared to past) was also recorded by Trávníček et al. (2006). However, the results showed large variability within both regions and farms.

According to Groppel (1993), at an equal dietary intake, the ovine and caprine colostrums and milk contain more iodine than the milk of dairy cows, and that iodine concentrations of $79 \mu \mathrm{g} \cdot \mathrm{l}^{-1}$ and $62 \mu \mathrm{g} \cdot \mathrm{l}^{-1}$ in the sheep and goat milk, respectively, are indicative of iodine deficiency. Ferri et al. (2003) reported the milk iodine content in sheep milk $675 \pm 154$ $\mu \mathrm{g} \cdot \mathrm{l}^{-1}$. Azuolas and Caple (1984) investigated 54 sheep flocks and average milk iodine 
concentrations ranged between 79 and $1831 \mu \mathrm{g} \cdot \mathrm{l}^{-1}$. Two flocks with the occurrence of goitre in lambs showed variations in the milk iodine content within $45-98 \mu \mathrm{g} \cdot \mathrm{l}^{-1}$. Similarly, Trávníček and Kursa (2001) investigated the milk iodine content in 10 sheep flocks and in 94 goats from 64 farms. An average iodine concentration in sheep milk was $105.5 \mu \mathrm{g} \cdot \mathrm{l}^{-1}$. The corresponding value for four farms where sheep had access to mineral licks ( $35 \mathrm{mg}$ iodine per $1 \mathrm{~kg}$ ) was $243 \pm 87.2 \mu \mathrm{g} \cdot \mathrm{l}^{-1}(107.7-436.6)$ and for the rest of the farms $47.9 \pm$ $27.8 \mu \mathrm{g} \cdot \mathrm{l}^{-1}$. Mean iodine concentrations in goat milk $\left(31.6 \mu \mathrm{g} \cdot \mathrm{l}^{-1}\right.$ and $63.0 \mu \mathrm{g} \cdot \mathrm{l}^{-1}$ in two consecutive years) were indicative of iodine deficiency. In goats receiving iodised salt, the average milk iodine concentration was $142.1 \pm 102.6 \mu \mathrm{g} \cdot \mathrm{l}^{-1}(51.8-39.6)$ and for the remaining goats $19.3 \pm 13.2 \mu \mathrm{g} \cdot \mathrm{l}^{-1}$. Average iodine concentration in goat milk on three farms with neonatal goitre occurrence ranged between 8.5 and $23.3 \mu \mathrm{g} \cdot \mathrm{l}^{-1}$.

Average iodine concentrations of iodine in sheep and goat milk recorded in our observation are presented in Table 6 .

Table 6. Milk iodine concentrations in sheep and goats $\left(\mu \mathrm{g} \cdot \mathrm{l}^{-1}\right)$ from various regions of Slovakia $(\mathrm{x} \pm \mathrm{SD})$

\begin{tabular}{|c|c|c|c|c|c|c|c|c|c|c|c|}
\hline & \multicolumn{8}{|c|}{ Sheep } & \multicolumn{3}{|c|}{ Goats } \\
\hline & \multicolumn{5}{|c|}{ East } & \multicolumn{2}{|c|}{ North } & Total & Middle & East & Total \\
\hline $\mathrm{x}$ & 106.1 & 57.0 & 668.2 & 62.4 & 254.3 & 55.9 & 116.0 & 186.7 & 48.0 & 89.2 & 73.7 \\
\hline SD & 109.5 & 7.6 & 432.4 & 2.9 & 296.8 & 7.2 & 441.1 & 287.6 & 2.4 & 25.6 & 28.6 \\
\hline median & 74.2 & 53.5 & 556.4 & 62.2 & 121.8 & 53.8 & 52.7 & 66.0 & 47.7 & 85.1 & 66.4 \\
\hline $\min$. & 59.1 & 50.2 & 207.1 & 59.1 & 60.2 & 49.5 & 47.8 & 47.8 & 45.4 & 62.7 & 45.4 \\
\hline $\max$. & 524.5 & 72.3 & 1613.2 & 67.0 & 1050.0 & 70.0 & 816.3 & 1613.2 & 51.9 & 146.0 & 146.0 \\
\hline $\mathrm{n}$ & 18 & 10 & 10 & 10 & 12 & 6 & 12 & 78 & 6 & 10 & 16 \\
\hline
\end{tabular}

Regarding limits indicating iodine deficiency (Groppel 1993), we found milk iodine concentrations below $80 \mu \mathrm{g} \cdot \mathrm{l}^{-1}$ in 49 sheep (62\%) and in 6 goats $(37.5 \%)$ below $60 \mu \mathrm{g} \cdot \mathrm{l}^{-1}$.

Milk iodine concentrations recorded in summer and winter feeding periods are presented in Table 7. When comparing seasonal differences, sheep and goat milk was higher in the iodine content during the winter feeding period, however, in dairy cows we recorded the opposite ratio. Except for goat milk $(p<0.01)$ the seasonal differences were not significant.

Table 7. Milk iodine concentrations in dairy cows, sheep, and goats $\left(\mu \mathrm{g} \cdot \mathrm{l}^{-1}\right)$ during summer and winter feeding periods $(\mathrm{x} \pm \mathrm{SD})$

Numbers with the same superscript differ at $p<0.01$

\begin{tabular}{|l|c|c|r|r|r|r|}
\hline & \multicolumn{2}{|c|}{ Summer feeding period } & \multicolumn{3}{c|}{ Winter feeding period } \\
\hline & Cows & \multicolumn{1}{c|}{ Sheep } & \multicolumn{1}{c|}{ Goats } & Cows & \multicolumn{1}{c|}{ Sheep } & Goats \\
\hline $\mathrm{x}$ & 154.6 & 56.0 & $48.0^{\mathrm{a}}$ & 126.6 & 197.6 & $89.2^{\mathrm{a}}$ \\
\hline SD & 309.2 & 7.2 & 2.4 & 223.3 & 296.8 & 25.6 \\
\hline median & 57.0 & 53.8 & 47.7 & 56.6 & 67.9 & 85.1 \\
\hline min. & 8.1 & 49.5 & 45.4 & 9.2 & 47.8 & 62.7 \\
\hline max. & 1790.6 & 70.0 & 51.9 & 1501.9 & 1613.2 & 146.0 \\
\hline $\mathrm{n}$ & 169 & 6 & 6 & 288 & 72 & 10 \\
\hline
\end{tabular}

Several authors reported higher milk iodine concentrations during the winter feeding period (Binnerts 1979; Groppel and Anke 1991; Dahl et al. 2003; Trávníček et al. 2006). Seasonal differences are explained by the lower iodine content in summer food rations. Iodine content increases due to water loss during plant biomass preservation. Hay and ensiled fodders have higher iodine content than green matter (Herzig and Suchý 1996; Bobek 1998). However, loss of iodine may occur during the drying and storing of foods (Kroupová et al. 2001). Opposite findings were reported by Azuolas and Caple (1984), who reported the highest milk iodine concentrations in late summer, decreasing during autumn to the lowest concentrations in spring. Similarly, Graham (1991) reported higher thyroid iodine content in summer and autumn than that in winter and spring. Seasonal differences in the milk iodine content may be related also to environmental temperature. According to Lengemann (1979), six times more iodine appeared in goat milk at 
environmental temperatures of $33{ }^{\circ} \mathrm{C}$ than at $5{ }^{\circ} \mathrm{C}$. The author suggested that at $33{ }^{\circ} \mathrm{C}$ less iodine is used for thyroxin production while the iodine concentrating mechanism continues in the mammary gland. High temperatures made more iodine available, made the mammary gland more efficient in clearing blood of iodine, and influenced the size of body iodine pool.

Regarding seasonal differences recorded in our study, the opposite summer-winter ratio of milk iodine content found in dairy cows (compared with sheep and goats) could be related to cattle feeding, which is not so strictly bound to summer and feeding periods as in small ruminants.

The bovine, ovine, and caprine milk iodine concentrations recorded in our study correspond to data published by various authors. When comparing various Slovak regions, we found the highest values in the Western, then Middle, Eastern, and the lowest values in the Northern Slovakia. Comparing seasonal differences, sheep and goat milk had higher iodine content during the winter feeding period; however, in dairy cows we recorded the opposite ratio. Yet, the results showed large variability within both regions and farms.

\section{Obsah jódu v mlieku na Slovensku}

Ciel'om práce bolo zmapovat' aktuálne koncentrácie jódu v surovom mlieku dojníc, oviec a kôz a ich sezónne rozdiely v rôznych regiónoch Slovenska. Koncentrácia jódu bola stanovená v 457 vzorkách surového kravského mlieka, 78 vzorkách ovčieho a 16 vzorkách kozieho mlieka odobraného v rokoch 2002 až 2007 v rôznych regiónoch Slovenska. Spomedzi 457 vzoriek kravského mlieka bol obsah jódu pod $50 \mu \mathrm{g} \cdot \cdot^{-1}$ zaznamenaný v 114 vzorkách $(24,94 \%) ; 294$ vzoriek $(64,33 \%)$ vykazovalo koncentrácie od 50 do 200 $\mu \mathrm{g} \cdot \mathrm{l}^{-1} ; 19$ vzoriek $(4,16 \%)$ od 200 do $500 \mu \mathrm{g} \cdot \mathrm{l}^{-1} ; 17$ vzoriek $(3,72 \%)$ medzi 500 a 1000 $\mu \mathrm{g} \cdot \mathrm{l}^{-1}$ a v 13 vzorkách $(2,85 \%)$ boli zaznamenané koncetrácie jódu nad $1000 \mu \mathrm{g} \cdot \mathrm{l}^{-1}$. Pri porovnaní rôznych regiónoch boli najvyššie koncetrácie jódu v mlieku zaznamenané na západnom, potom strednom a východnom Slovensku, najnižšie koncentrácie boli zistené na severnom Slovensku $(p<0,05, p<0,01)$ Vo vzorkách ovčieho a kozieho mlieka sme zistili koncentrácie jódu pod $80 \mu \mathrm{g} \cdot \mathrm{l}^{-1} \mathrm{u} 49$ oviec $(62,8 \%)$ a u $6 \mathrm{kôz}$ pod $60 \mu \mathrm{g} \cdot \mathrm{l}^{-1}(37,5 \%)$, pričom tieto hodnoty poukazujú na deficit jódu. Porovnanie sezónnych rozdielov koncentrácie jódu v mlieku oviec a kôz ukázalo vyššie koncentrácie počas zimného kŕmneho obdobia, avšak u dojníc sme zaznamenali opačnú tendenciu. S výnimkou kozieho mlieka $(p<0,01)$ sezónne rozdiely neboli významné.

\section{Acknowledgement}

This work was supported by the Slovak Research and Development Agency under the contract No APVV 20-027905.

\section{References}

ANKE M, DORN W, GUNSTHEIMER G, ARNHOLD W, GLEI M, ANKE S, LÖSCH E 1998: Effect of trace and ultratrace elements on reproduction performance of ruminants. Vet Med-Czech 43: 272-282

AZUOLAS JK, CAPLE IW 1984: The iodine status of grazing sheep as monitored by concentrations of iodine in milk. Aust Vet J 61: 223-227

BINNERTS WT 1979: The iodine content of milk: No reason for concern yet. Neth Milk Dairy J 33: 12-23

BOBEK S 1998: Iodine prophylaxis in animals. Med Weter 54: 80-86

BORKOVCOVÁ I, ŘEHURKOVÁ I 2001: Study of iodine exposure in foodstuffs (in Czech). Rep Natl Inst Public Health 6: 5-8

BRAVERMAN LE, VAGENAKIS AG, WANG CA, MALOF F, INGBAR SH 1971: Studies on the pathogenesis of iodine myxedema. Trans Assoc Am Physicians 84: 130-135

DAHL L, OPSAHL JA, MELTZER HM, JULSHAMN K 2003: Iodine concentration in Norwegian milk and dairy products. Br J Nutr 90:679-685

DELLAVALLE ME, BARBANO DM 1984: Iodine content of milk and other foods. J Food Prot 47: 678-684

FERRI N, ULISSE S, AGHINI-LOMBARDI F, GRAZIANO FM, DI MATTIA T, RUSSO FP, ARIZZI M, BALDINI E, TRIMBOLI P, ATTANASIO D, FUMAROLAA, PINCHERAA, D'ARMIENTO M 2003: Iodine supplementation restores fertility of sheep exposed to iodine deficiency J Endocrinol Invest 26: 1081-1087 
FOOD CODE OF THE SLOVAK REPUBLIC: Appendix No 5 to the seventh chapter of the second part of the Food Code. Amount of minerals in milk of dairy cows (in Slovak). www.svssr.sk/sk/legislativa/kodex/2_07_05.pdf

GÖRNER F, KOLLÁR F, HAVELKA B, KNOP J 1979: Problem of iodine content in milk (in Czech). Veterinářství 10: $445-446$

GRAHAM TW 1991: Trace element deficiencies in cattle. Vet Clin N Am-Food Anim Pract 7: 153-215

GROPPEL B 1993: Jodmangel beim Tier. In: ANKE M, GÜRTLER H (Eds): Mineralstoffe und Spurenelemente in der Ernährung. Gersdorf, Verlag Media Tourustik, pp. 127-156

GROPPEL B, ANKE M 1991: Iodine content in foodstuffs and iodine intake of adult in central Europe. In: MOMČILOVIČ B. (Ed.): Trace elements in man and animals. Vol. 7. University of Zagreb, Yugoslavia: pp. 6-7

HEMKEN HRW 1979: Factors that influence the iodine content of milk and meat: A review. J Anim Sci 48: 981-985

HEMLING TC 2001. Iodine in milk. Milk production. DeLaval dairy knowledge international. Tumba, Sweden. Accessed on October 25 th 2006 at http://www.milkproduction.com/Library/Articles/Iodine_in_Milk.htm.

HERMANSEN JE, AAES O, OSTERSEN S, VESTERGAARD M 1995: Rapeseed products for dairy cows milk yield and milk quality. Forskningsrapport fra Statens Husdyrbrugsforsog 29: 1-31

HERZIG I, SUCHÝ P 1996: Current views on the importance iodine for animals. Vet Med-Czech 41: 379-386

HERZIG I, PÍSAŘÍKOVÁ B, KURSA J, ŘÍHA J 1999: Defined iodine intake and changes of its concentration in urine and milk of dairy cows. Vet Med-Czech 44: 35-40

KRAJČOVIČOVÁ-KUDLÁČKOVÁ M, BUČKOVÁ K, KLIMEŠ I, SEBOKOVA E 2001: Iodine deficiency at alternative and traditional nutrition. Bull Food Res 40: 311-319

KROUPOVÁ V, HERZIG I, KURSA J, TRÁVNÍČEK J, THÉR R 2001: Level of iodine intake by cows in Czech Republic. Veterinářství 51: 155-158

LENGEMANN FW 1979: Effect of low and high ambient temperatures on metabolism of radioiodine by the lactating goat. J Dairy Sci 62: 412-417

MEE JF, ROGERS PAM 1996: Prevalence of iodine, selenium, copper and cobalt deficiencies on Irish cattle farms. Irish Vet J 49: 160-164

PARK YK, HARLAND BF, VANDERVEEN JE, SHANK FR, PROSKY L 1981: Estimation of dietary iodine intake of Americans in recent years. J Am Diet Assoc 79: 17-24

ŠUCMAN E, CVAK Z, KALOUS F, SYNEK O 1984: Some questions concerning the iodine content in milk. Acta Vet Brno 53: 65-69

SWANSON EW, MILLER JK, MUELLER FJ, PATTON CS, BACON JA, RAMSEY N 1990: Iodine in milk and meat of dairy cows fed different amounts of potassium iodine or ethylenediamine dihydroiodide. J Dairy Sci 73: $398-405$

TRÁVNÍČEK J, KURSA J 2001: Iodine concentration in milk of sheep and goats from farms in South Bohemia. Acta Vet Brno 70: $35-42$

TRÁVNÍČEK J, HERZIG J, KURSA J, KROUPOVÁ V, NAVRÁTILOVÁ M 2006: Iodine content in raw milk. Vet Med-Czech 51: 448-453

TRÁVNÍČEK J, KROUPOVÁ V, ŠOCH M 2004: Iodine content in bulk feed in western and southern Bohemia. Czech J Anim Sci 49: 483-488

TŘINÁCTÝ J, ŠUSTALA M, VRZALOVÁ D, KUDRNA V, LANG P 2001: Milk iodine content in cows fed rapeseed meal iodine supplement. In: Book of abstracts of the $52^{\text {nd }}$ Annual Meeting of the European Association for Animal Production, 26 - 29 August 2001, p. 106

TUŠL J 1983: Fotometrické stanovení stop jodu v potravinách na základě katalytické reakce NO-2/SCN-. (Photometric determination of iodine trace amounts in food by catalytic reaction NO-2/SCN-, in Czech). Chem Listy 77: 513-515

WAYNE EJ, KOUTRAS DA, ALEXANDER WD 1964: Clinical aspects of iodine metabolism. Blackwell, Oxford, $303 \mathrm{p}$.

WOLFF J 1969: Iodine goiter and the pharmacological effects of excess iodine. Am J Med 47: 101-124 